\title{
Theology and the (post-)apartheid university: Mapping discourses, interrogating transformation
}

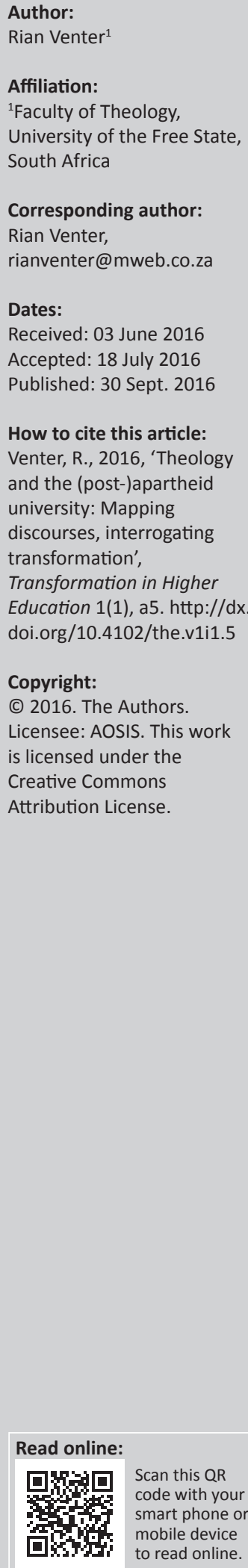

\begin{abstract}
This article examines the specific position of Theology at South African universities, following the recent developments on campuses that catapulted the urgency for greater commitment to radical transformation in higher education to public attention. A large corpus of material is generated on theological education as such, but the major question is rarely thematised as the transformation of Theology at public universities in (post-)apartheid South Africa. This article addresses the nature of the challenge by following a distinct approach. Ten major discourses in the wider reflection on theological education are identified and interpreted as avenues to achieve three aims: to convey the unique challenge for Theology, to give historical texture to issues conventionally addressed a-politically in Theology and to forward an interpretation of 'transformation' for Theology that emphasises its multi-layered nature.
\end{abstract}

\section{Introduction: Identifying the landscape}

The various \#MustFall movements on South African university campuses in 2015 have made the overwhelming impression that transformation should be addressed with renewed urgency and be appreciated for its complex nature. Higher education has come a long way since 1994, but something is amiss. The positive spin-off of last year's turmoil is the generation of the imperative to think afresh about the nature of transformation. This article is interested in one specific field of study, Theology, and what renewed reflection might entail for it.

Although the influence of Theology has diminished owing to various reasons, of which growing secularisation has played no small role, it is still accorded intellectual space in several public universities. What would transformation for this distinct field of study imply? Despite yearning for the stable and the immutable, Theology and theological education could never be immunised from the larger social context. In the apartheid era, Theology, at some institutions, provided religious legitimisation to the racial ideology. This no longer happens, but the question arises as to whether Theology has re-envisioned itself sufficiently to make a responsible and meaningful social contribution in a new democratic dispensation.

This article pursues a distinct line of argumentation: it maps and explores contemporary discourses taking place in Theology and theological education, with the purpose of gaining better insight into the multifaceted challenge of transformation. It would have been possible to describe the challenge of transformation in general terms, but by following this approach, the article endeavours to integrate a large range of discussions and perspectives and focus them all on the central concern of transformation. The massive and important volumes of essays by the World Council of Churches (see the two applicable ones to the South African context - Phiri \& Werner 2013; Werner et al. 2010) evidence the extent of the vibrant international discourses. What also transpires from these reflections is the neglect to address the notion of the public university and the uniquely South African transformation imperative for Theology. Anyone acquainted with the debates on theological education (for excellent treatments of overviews, see González 2015; Miller 2014; Wingate 2005) would not only testify to the myriad questions at stake but also to a specific hiatus - a clarification of the radical nature of the challenge to transformation. This article aims to identify the major discourses, draw explicit attention to the best available scholarship, and profile in the process a multi-layered notion of transformation.

\section{Mapping the contours}

\section{The institutional space: Facing the irony}

The first discourse expresses a strange irony: the 'queen of sciences' has fallen from grace (for the long history of this development, see Zakai 2007). With seismic shifts, especially in Western consciousness and the growth of secularism, the very religious and specifically Christian underpinnings to the 
emergence of universities in the late medieval period are increasingly dismissed, and Theology receives a lukewarm, if not outright hostile, welcome at public universities. Often, the 'numbers-game' speaks louder than ideological considerationsfaculties of Theology are smaller than some departments in other fields of study and are not as profitable. The questions in this discourse are clear: should Theology still receive space at a public institution such as a university, and what are the implications of such a location in a pluralistic and democratic country for Theology itself? This is not only a major international debate (see D'Costa 2005; Hauerwas 2007; Kelsey 2009; Werner 2012) but also one that has been addressed in South Africa (see Venter 2011; Wethmar 1996). Whether the ramifications of a university setting have been fully grasped and adequately theorised locally is an open question. Some churches, especially those of Reformed orientation, still deem that the faculties are 'theirs' and that church oversight committees have a valid power base. Historically, the study of Theology and theological education has been institutionalised in diverse forms, for example, in ecclesiastical seminaries, or even at church-oriented universities, and the question where Theology should be primarily located is a perennial one (see Brown 1994). Some churches prefer private institutions; Reformed churches in South Africa have consistently realised the importance of the public university. What is required is a clear sense of the rationale for location at a public university and the implications of such a space. The shape of challenge of a public tertiary location should be identified and is arguably one of legitimisation: Why should Theology be accommodated at a public university; Does the knowledge, transmitted and generated, serve public good or narrow sectional interests? In the South African context, this question of legitimisation has an unavoidable historical specificity: What is the epistemic contribution to this society with its particular history and present moment? A large number of auxiliary and related questions surface in this discourse: the relation of Theology to the humanities (see Brittain \& Murphy 2011; Lategan 1993) and the relationship with churches. This discourse requires the participation of three stakeholders, namely universities, faculties of Theology and churches (see Tracy 1981:3-46). At stake are not only fundamental issues such as the role of transcendence in society, and the social ethic of knowledge, but also imperatives of plurality and enlarged identities. If Theology experiences her final demise at public universities, it would immensely impoverish all partners (see Lombaard 2016:1-5). The enriching dialectic is critical, in this instance: on the one hand, it furthers humanisation, the deepening quest for transcendence implicitin all epistemological endeavours at universities and, on the other, it nurtures openness, and the forming of inclusive and pluralistic identities in Theology and religious communities. In South Africa, this discourse still has a long way to go: for institutions, to realise the potential of religion to humanise, and for Theology and religion, to escape from fundamentalist propensities.

\section{The post-apartheid condition: Embracing transformation}

'Transformation' is a heuristic term that refers to changes in higher education in post-1994 South Africa. The referent is the apartheid ideology and its pervasive manifestations in all areas of society, as well as at universities. At stake is the undoing of the vast discriminatory practices and systems, and establishing of comprehensive justice. Numerous changes have taken place in Theology. Some faculties have been phased out; some departments have been reconfigured; access and appointment of persons either excluded or marginalised have happened; and curricula have been revisited. Landman (2013:239), in her overview of theological education in South Africa, even claims 'Over the past thirty years, theological education in South Africa has developed from being white, male and/or denominational to liberational, ecumenical and inclusive of gender, race and belief'. The question could, however, be raised as to what extent have Theology practitioners adequately theorised the imperative for transformation. Deeper and more hidden traces of colonialist, modernist, racialised and even patriarchal power dynamics often escape scrutiny, especially in the epistemic practices in the curricula and research agendas and paradigms. The dominance of certain intellectual traditions, especially the Reformed one, at the four remaining faculties of Theology (Bloemfontein, Potchefstroom, Pretoria and Stellenbosch) is still a huge remnant of the past. The \#MustFall movements of 2015 have stimulated a renewed sense of seriousness to the debate on the pace and depth of transformation. The important Second National Higher Education Summit on Transformation ${ }^{1}$ re-emphasised the incomplete task ahead. The comprehensive and radical nature of the challenge becomes increasingly clear: it includes issues not only of access, staffing, leadership and finance but also of institutional culture, pedagogical approaches, symbols, language and knowledge. One could also refer to the human, the knowledge and the institutional dimensions. Some crucial attempts have already been made to theorise these deeper reaches of transformation (see Naude 2004; Venter \& Tolmie 2012; Venter 2015). This line of exploration should be pursued. 'Epistemological transformation' has become an apt shorthand description to refer to these critical and deeper contours of transformation. This refers to questions such as whose knowledge is transmitted, for whom is knowledge generated and to what effect? This discourse highlights the very nature of knowledge, its interaction with society and its intrinsic ethical character. In some sense, this epistemological dimension of transformation is the prism that refracts the light of reflection in the various discourses, including those identified in this article. Whatever we discuss can hardly escape the power/knowledge reality.

\section{A new contextual Theology: Finding orientation again}

At the heart of the struggle of Theology to come to terms with the challenge of transformation is the need for a new contextual Theology, one that adequately responds to the post-apartheid context in its multifaceted character. Prior to 1994, apartheid provided a centripetal force to prophetic and ethically sensitive theologies. Since the advent of democracy, it seems that churches and Theology have lost an orientating

1.See www.dhet.gov.za/summit for papers presented. 
compass (for good discussions of this dilemma, see Cuthbertson 2008; Egan 2007). There is evidently no clear direction as to which way Theology should go. This does not at all imply that commendable work is not being undertaken; such an impression would do a great disservice to serious theological scholarship. Major research contributions have been made, for example, on public Theology (see De Villiers 2011), on ecology (see Conradie 2013), on feminist Theology (see Haddad 2013) and on the faith/science dialogue (see Conradie \& Du Toit 2015). Apart from these new 'trends', traditional theological disciplines have been revisioned, for example, the Old Testament (for an overview, see Bosman 2015). The impressive oeuvres of scholars such as J de Gruchy and D Smit, who have consistently produced quality theological work with a sensitive antenna to the South African context, should be acknowledged (for only one example of their respective contributions, see the volume by Marks 2008). Despite the presence of commendable contributions, one cannot but escape the impression that something is neglected: an orientation that discerns the myriad of social changes, seizes the deep cynicism in the present South African mind, and speaks to the heart of Africa. In its various disciplinary manifestations, the discourse is too diverse, too fragmentary. A more integrative theological project is necessary. It may even be questioned whether such a Theology is at all possible. The Finnish scholar V-M Kärkkäinen has embarked on an ambitious systematic theological project, which he calls A constructive Christian Theology for the pluralistic world, and in which he emphasises the requirements of coherence, inclusiveness, dialogue and hospitality (see the introduction to the first volume 2013:1-35). Perhaps, something similar is required for the South African context but translated into the realities of the post-apartheid context. Coupled with a Theology of justice, such an orientation could encourage simultaneously a memory of the past, an attentiveness to persistent forms of suffering and a respect for the plurality of intellectual traditions, and for the multiple voices of the conventional other. As long as Theology, in its disciplinary embodiments, does not subject its very nature to scrutiny, it would not be able to engage deep transformation.

\section{The publics of Theology: Broadening allegiances}

Traditional Theology has been intimately linked to the church; it is a function of the church and should serve the life of the church. This was tenable in a dispensation where higher education served narrow nationalist purposes; Theology, by implication, provides religious sanction. This becomes obviously problematic in a democracy. Confessional Theology is by nature exclusionary, and public institutions cannot fund education that only benefits certain sections. It is understandable that the changing situation at universities becomes alienating to churches. Where Theology was previously nurturing growth in a narrow and well-defined tradition, the new situation has become more complex and even unsettling. The transition to inclusive democratic public universities in South Africa renders reflection on the three publics of Theology - church, society and academy - critically important (for a good discussion of this, see the 1991 article by Bosch who applies the insights of Tracy to the South African context) and exposes the irony of traditional approaches. While expounding a universalising interpretation of reality with its confession of creation, salvation and cosmic destiny, ironically confessional Theology tends to narrow these implications to very discrete social embodiments. Whether confessional Theology with a focus on church could still be defended at a public institution becomes a contested issue (see Deist 1994). Perhaps, the advent of a new set of values at universities opens a potentially enriching opportunity for Theology. The social and intellectual capacities of religious traditions could be interrogated, explored and imaginatively revisioned for the common good. This shift from a narrow community interest to a broader social application is a major trajectory deviation for Theology. Service to the common good is a new situation for Theology (for a discussion of universities and the pursuit of 'common good', see Leibowitz et al. 2012b). The shape of the challenge crystallises in the notion of accountability. The role of church oversight committees (traditionally, the so-called 'curatoria') has obviously diminished, if not totally becoming untenable. If a criteriology of meaningfulness should be construed, social impact and multidisciplinary participation should minimally be considered. In his recent work Flourishing (2015), Volf thinks along these lines: in a globalised world, religion can make a contribution to human well-being. The ramifications of this for Theology in a South African context are obvious. The imperative of transformation is a fruitful stimulus for Theology to rethink its basic nature, task and function. Ultimately, it could even encourage Theology to design a programme, for example, in spirituality and ethics, which opens career options way beyond ecclesiastical vocations.

\section{Theology versus religious studies: Rethinking power/method}

In the previously mentioned discourses, no distinction was made between (Christian) Theology and the study of religion. The assumption has been implicit that 'Theology' refers to the Christian faith. Transformation at public universities requires that this relationship be subjected to scrutiny. This is not only a South African but also an acute international challenge (see, for example, good treatments from a variety of viewpoints Bird \& Smith 2009; Cady \& Brown 2002; Fiorenza 1991; UK Benchmark Statement 2007). The shape of the question of the relationship has a particular genealogy: in a colonial era, the study of religion was situated in the subject-discipline of Missiology; Theology has been exclusively the study of Christianity; and, if studied outside the parameters of mission, religion was relegated to a department that dealt with the world-religion phenomenologically. The implications of this configuration should be understood: one religion Christianity - was privileged, and a distinction was made methodologically between the presence of faith convictions and supposedly value-free study. Both these premises have become contested. The playing field has been levelled and all religions should be equally respected and valued. With the emergence of constructionist understandings of human 
knowledge, a positivist approach to religion is questionable; academic study will always pre-suppose some form of values and interests. It is not yet clear how this discourse will eventually impact practical arrangements at universities. What is inevitable, however, is greater attention to the study of Islam and African religion, ${ }^{2}$ as well as scholarly involvement of practitioners of these religions. How coherence is to be established in a sea of intellectual traditions will be a daunting task. The benefits of greater inclusion should not be missed: the study field will be expanded from a narrow ecclesial focus to one that prioritises human quests for transcendence, meaning-making and planetary flourishing.

\section{Fragmentation of the disciplines: Searching for integration}

The present encyclopaedia of Theology, that is, the division of subject disciplines, displays a vast compartmentalisation of knowledge. The separate fields of Old and New Testaments, Systematic Theology and Ethics, Church History and Polity and Practical Theology and Missiology manifest a typical modernist rationality with its separation and specialisation. Justifiably, much discontent has been voiced internationally over the past few decades (see, for example, the book by Farley 1983; Welker \& Schweitzer 2005). Not only does this state of affairs have an adverse effect on effective student learning and Christian ministry, but it also hides Theology's ability to engage with complex social problems such as, for example, alterity, racism and poverty. Alternative reconfigurations of the disciplines in a triad structure of texts, beliefs and practices are often enthusiastically discussed, but the fragmentation of the disciplines is rarely, if at all, placed in the context of the imperative of transformation. Once this occurs, the self-directedness of most disciplines transpires. Most often disciplines serve the scholarly societies of the disciplines and not those of the general public. When the alienation is placed in the frame of interdisciplinarity, wider conversations crystallise, for example, between Theology and the natural sciences, Theology and the arts, and Theology and cultural theory. The dialogical nature of theologising is thus highlighted and the epistemic source base is broadened. Interdisciplinarity could serve as an epistemic vehicle to address complexity. Urgent social challenges such as, for example, those pertaining to reconciliation and sexuality could in this way be treated in a much more intellectually satisfying manner. A great deal of work is still to be done in this regard.

\section{Epistemology and alterity: Re-imagining knowledge}

All the various challenges in the quest for transformation of Theology could arguably be contracted in a single denominator: inclusion and epistemic justice. The violence of apartheid is to be found in its exclusionary nature. As reference to those who have been marginalised or denigrated in terms of their gender, ethnicity, culture and sexuality, 'alterity' becomes a crucial optic for considering transformation. Knowledge has been constructed from primarily Western, male and bourgeoisie perspectives. This is obviously a sophisticated discourse, as it addresses subtle power dynamics that are not always so visible but immensely decisive to shape a social order. Good work has already been done and note should be taken, for example, of that on woman and theological education (Chopp 1995; Trisk 2015). As part of this discourse, the critical debate on 'Africanising the curriculum' should be addressed (see the volume by Msila \& Gumbo 2016). What this entails for Theology has been the subject of investigation for quite some time (see, for example, Amanze 2012; Buitendag 2014; Higgs 2015; Maluleke 2006; Maluleke \& Nadar 2004; Naidoo 2016; Walls 2002). What progress has already been made to reconstruct curricula is an open question. Where there is some openness to alterity and inclusion, often the corpus of knowledge is treated as an 'add-on', not the fundamental perspective to reconceptualise the entire curriculum. The basic texture of the curriculum remains the same - African lies only in the extension of a Western rationality. The simple, but profound, questions about whose knowledge and knowledge for whom should be taken very seriously. The nature of epistemic paradigms, of methodologies, of rhetoric or of truth construction and of language comes into play. The ramifications of this project will be far-reaching. Womanist, African and postcolonial theologians have already produced a great deal of work on this subject. The fabric of religious traditions could be redefined in this process.

\section{Ecology of student life: Striving to be 'at home'}

The presence of the problematic features identified in the previous discourses has a combined effect of generating pervasive alienation among students on South African university campuses. The various \#MustFall movements introduced a distinct 'turn to the student' dimension in the transformation reflection since 2015. Symbols, fees, language and even the employment conditions of service workers are important constituents of a new university ethos. At stake is a comprehensive creation of an alternative institutional culture, a culture that replaces the apartheid legacy. The resurfacing of the debate on race is also not surprising in this regard (see, for example, the good collection of essays by Mangcu 2015). The notion of the 'ecology of student life' could be employed to refer to the presence and dynamics of multiple factors that build a tertiary and epistemic home. Some good research has also been done on the task to let students 'feel at home' (see the volume by Tabensky \& Matthews 2015). The face of theological faculties in South Africa has changed, and the student profile has become much more diverse and inclusive. Whether adequate and substantial thinking has taken place on intercultural theological education is doubtful. It is worth taking note of the national and international reflection in this regard (see Dames 2010; Esterline \& Kalu 2006; Fernandez 2014). Conditions that do not inhibit students, but respect their agency, are to be created and nurtured. 


\section{Formation: Accounting for student attributes}

The 'turn to the student' has another dimension amounting to a separate discourse: formation. The notion of detached knowledge has become obsolete; a sense that all knowledge in its transmission and generation is deeply imbued with concerns and interests has become dominant. This becomes apparent in the performative effect of the knowledge encounter. The entire epistemic experience shapes the consciousness and forms the identity of students. In the general higher education discussion, this has become critical and the focus is on the need to address the quality of future citizenship (see, for example, the volume by Leibowitz et al. 2012a). In theological education, the issue has taken its own distinct shape internationally, well-formulated by Kelsey (1993) whether an 'Athens' or a 'Berlin' emphasis is followed, that is, whether intellectual scholarship or character is prioritised. In South Africa, scholars such as Conradie (1997) and Naidoo (2008), in particular, have attended to the complexity and urgency of this challenge. Conventionally, theological education has mainly focused on nurturing a specific denominational tradition, for example, introduction to, and growth in the Reformed tradition. Churches often lament that faculties neglect traditional identity formation. The transformation imperative immeasurably contests this narrow concept of identity and advocates more 'catholic selves'. The constructive of student selves through the entire educational process should be intentionally approached in light of a specific political past, contemporary social exigencies and a globalised world. The church debate on identity should be rephrased in concrete historicised terms, and move beyond the propensity to privatised knowledge as if it concerns the individual sanitised from larger social conflicts. The South African landscape is littered with pathological attitudes of cynicism, intolerance of the other and insensitivity to justice. Theology is exceptionally suited to project an alternative world of hope, respect and flourishing. In this regard, Theology could make a most fruitful contribution to public universities.

\section{Theological Theology: Witnessing uniqueness}

The danger is real that the study of religion and Theology could be reduced to merely the exposition of a civil religion for the sake of social ethical functions. That a sense of Transcendence, of the Ultimate and the Sacred could be eclipsed in the drive for social relevance should be faced. The question becomes one of the inalienable, unique and distinct contribution of religion and Theology. In a Christian sense, this has been thematised as seeking the theological dimension of Theology. Good international and local literature is also available (see, for example, Kelsey 1992; Robinson \& Smit 1996; Smit 1993; Volf 2005). The symbol of the Divine or of God becomes central in this discourse, and the shape of the challenge is to explore to what extent this Reality could have fruitful existential, social and cosmic meaning. Life's socalled 'big questions' about origin and destiny, truth and goodness, identity and community, and justice and hospitality are addressed from this metaphysical perspective.
God concepts are constructions, and the task ahead for Christian Theology is daunting and exciting: to retrieve an acute sense of the Triune God, and to explore the potential of this symbol to contribute to human flourishing in a specific and concrete context. Obviously, the freedom and hiddenness of God should be honoured; but, the Christian symbol and its distinct genealogy is an immense epistemic resource to deepen the conversation on transformation. In a Christian sense, this is a soteriological notion, and it refers to holistic healing of the human society and the cosmos. This theological discourse could contribute to expand and deepen the debate on transformation. It introduces the question about ultimate values and orientations (for a discussion of God and the public university, see Venter 2013).

\section{Conclusion \\ Navigating a direction}

By approaching an exploration of transformation via an identification of 10 major discourses taking place in Theology about the future of theological education at public institutions, a complex and multifaceted notion gradually emerges. A new way of doing Theology is required, a new re-imagining that would take its locale at a public institution within the specific (post-) apartheid context with utmost seriousness. The well-being of the common good becomes a primary referent. This would require a rethinking of the traditional divide between religion and Theology, and the fragmentation of the sea of disciplines. At the heart of the knowledge project is epistemic justice, which requires the inclusion of neglected voices and experiences of those conventionally ignored and suppressed. The performative effect of the knowledge transmitted becomes a matter of scrutiny, as students should be formed in a way that enables them to function in a new society. Central to the theological transformation is reconstruction of its central symbol - the rethinking of the divine in ways that promote flourishing. How all this will concretely play out in each institution will vary in light of its unique ecology, but the main direction is fairly clear.

\section{Competing interests}

The author declares that he has no financial or personal relationships which may have inappropriately influenced him in writing this article.

\section{References}

Amanze, J.N., 2012, 'The voicelessness of Theology and religious studies in contemporary Africa: Who is to blame and what has to be done? Setting a new agenda', Missionalia 40(3), 189-204.

Bird, D.L. \& Smith, S.G. (eds.), 2009, Theology and religious studies in higher education: Global perspectives, Continuum, London.

Bosch, D.J., 1991, 'The nature of theological education', Journal of Theology for Southern Africa 77, 3-17.

Bosman, H.L., 2015, 'Ants, spiders or bees ... and ticks? A typology of Old Testament scholarship in South Africa since 1994 within its African context', Old Testament Essays 28(3), 636-654. http://dx.doi.org/10.17159/2312-3621/2015/v28n5a5

Brittain, C.C. \& Murphy, F.A. (eds.), 2011, Theology, university, humanities: Initium sapientiae timor Domini, Cascade, Eugene, OR.

Brown, E., 1994, 'Kweekskool teenoor teologiese fakulteit: Die ervaring van die Nederduitse Gereformeerde Kerk', Hervormde Teologiese Studies 50(1\&2), 68-94. http://dx.doi.org/10.4102/hts.v50i1/2.2544 
Buitendag, J., 2014, 'Between the Scylla and the Charybdis: Theological education in the 21st century in Africa', Hervormde Teologiese Studies/Theological Studies the 21st century in Africa', Hervormde Teologiese Studies/The
70(1), Art. \#2855, 1-5. http://dx.doi.org/10.4102/hts.v70i1.2855

Cady, L.E. \& Brown, D. (eds.), 2002, Religious studies, Theology, and the university: Conflicting maps, changing terrain, SUNY Press, Albany, NY.

Chopp, R.S., 1995, Saving work: Feminist practices of theological education, Westminster John Knox, Louisville, KY.

Conradie, E.M., 1997, 'An ABC in theological education', Nederduits Gereformeerde Teologiese Tydskrif 38(4), 349-361.

Conradie, E.M., 2013, 'Contemporary challenges to Christian ecotheology: Some reflections on the state of the debate after five decades', Journal of Theology for Southern Africa 147, 106-123.

Conradie, E.M. \& Du Toit, C.W., 2015, 'Knowledge, values, and beliefs in the South African context since 1948: An overview', Zygon 50(2), 455-479. http://dx.doi. African context since 1948
org/10.1111/zygo.12167

Cuthbertson, G., 2008, 'South Africa's democracy: From celebration to crisis', African Identities 6(3), 293-304. http://dx.doi.org/10.1080/14725840802223606

Dames, G., 2010, 'Intercultural theological education: Towards a new future for faculties of Theology at higher education institutions in South Africa', Scriptura 110, 237-248. http://dx.doi.org/10.7833/110-0-113

D'Costa, G., 2005, Theology in the public square: Church, academy and nation, WileyBlackwell, Oxford.

De Gruchy, J.W., 2008, 'Constructing a South African theological mind', in D.C. Marks (ed.), Shaping a global theological mind, pp. 35-39, Ashgate, Hampshire.

Deist, F.E., 1994, 'Moet teologiese opleiding kerklik-konfessioneel wees?', Hervormde Teologiese Studies 50(1\&2), 53-67. http://dx.doi.org/10.4102/hts.v50i1/2.2543

De Villiers, E., 2011, 'Public Theology in the South African context', International Journal of Public Theology 5, 5-22. http://dx.doi.org/10.1163/156973211X543715

Egan, A., 2007, 'Kingdom deferred? The churches in South Africa, 1994-2006', in S Buhlungu et al. (eds.), State of the nation: South Africa 2007, pp. 448-469, HSRC Press, Cape Town.

Esterline, D.V. \& Kalu, O.U. (eds.), 2006, Shaping beloved community: Multicultural theological education, Westminster John Knox, Louisville, KY.

Farley, E., 1983, Theologia: The fragmentation and integration of theological knowledge, Fortress, Philadelphia, PA.

Fernandez, E.S. (ed.), 2014, Teaching for a culturally diverse and racially just world, Cascade Books, Eugene, OR.

González, J.L., 2015, The history of theological education, Abingdon, Nashville, TN.

Haddad, B., 2013, 'The South African women's theological project in historical perspective', Journal of Theology for Southern Africa 145, 35-58.

Hauerwas, S., 2007, The state of the university: Academic knowledges and the knowledge of God, Blackwell, Oxford.

Higgs, P., 2015, 'The African Renaissance and the decolonisation of theological education', in M. Naidoo (ed.), Contested issues in training ministers in South Africa, pp. 43-56, SUN MeDIA, Stellenbosch.

Kärkkäinen, V.-M., 2013, Christ and reconciliation: A constructive Christian Theology for a pluralistic world, 1, Eerdmans, Grand Rapids, MI.

Kelsey, D.H., 1992. To understand God truly: What's theological about a theological school?, Westminster John Knox, Louisville, KY.

Kelsey, D.H., 1993, Between Athens and Berlin: The theological education debate, Eerdmans, Grand Rapids, MI.

Kelsey, D.H., 2009, 'Theology in the university: Once more, with feeling', Modern Theology 25(2), 315-327. http://dx.doi.org/10.1111/j.1468-0025.2008.01521.x

Landman, C., 2013, 'Theological education in South Africa', in I.A. Phiri \& W. Werner (eds.), Handbook of theological education in Africa, pp. 239-245, Cluster, Pietermaritzburg.

Lategan, B.C., 1993, 'Teaching Theology in the context of the humanities', Scriptura S11, 28-35.

Leibowitz, B. (ed.), 2012b, Higher education for the public good: Views from the South SUN MeDIA, Stellenbosch.

Leibowitz, B., Swartz, L., Bozalek, V., Carolissen, R., Nicholls, L. \& Rohleder, P. (eds.), 2012a, Community, self and identity: Educating South African university students for citizenship, HSRC Press, Cape Town.

Lombaard, C., 2016, 'Theological education, considered from South Africa: Current issues for cross-contextual comparison', HTS Teologiese Studies/Theological Studies 72(1), 1-5, http://dx.doi.org/10.4102/hts.v72i1.2851

Maluleke, S.M. \& Nadar, S., 2004, 'Alien fraudsters in the white academy: Agency in gendered colour', Journal of Theology for Southern Africa 120, 5-17.

Maluleke, T.S., 2006, 'The Africanization of theological education: Does theological education equip you to help your sister?', in E.P. Antonio (ed.), Inculturation and postcolonial discourse in African Theology, pp. 61-76, Peter Lang, New York.

Mangcu, X. (ed.), 2015, The colour of our future: Does race matter in post-apartheid South Africa? Wits University Press, Johannesburg.
Marks, D.C. (ed.), 2008, Shaping a global theological mind, Ashgate, Hampshire.

Miller, G.T., 2014, Piety and plurality: Theological education since 1960, Cascade Books, Eugene, OR.

Msila, V. \& Gumbo, M. (eds.), 2016, Africanising the curriculum: Indigenous perspectives and theories, SUN MeDIA, Stellenbosch.

Naidoo, M., 2008, 'The call for spiritual formation in Protestant theological institutions in South Africa', Acta Theologica. Supplementum 11, 128-146.

Naidoo, M. (ed.), 2015, Contested issues in training ministers in South Africa, SUN MeDIA, Stellenbosch.

Naidoo, M., 2016, 'Overcoming alienation in Africanising theological education', Hervormde Teologiese Studies/Theological Studies 72(1), Art. \#3062, 1-8. http:// dx.doi.org/10.4102/hts.v72i1.3062

Naude, P., 2004, 'Is there a future for scholarship? Reformed theological scholarship in a transforming higher education environment', Journal of Theology for Southern Africa 119, 32-45.

Phiri, I.A. \& Werner, D. (eds.), 2013, Handbook of theological education in Africa, Cluster, Dorpspruit.

Robinson, P.J. \& Smit, D.J., 1996, 'What makes theological education "theological"? A South African story on the integrity of theological education', Skrif en Kerk 17(2), 405-419. http://dx.doi.org/10.4102/ve.v17i2.527

Schüssler Fiorenza, F., 1991, 'Theological and religious studies: The contest of the faculties', in B.G. Wheeler \& B. Farley (eds.), Shifting boundaries: Contextual approaches to the structure of theological education, pp. 119-149, Westminster John Knox, Louisville, KY.

Smit, D., 1993, 'What makes theological education theological? Overhearing two conversations', Scriptura 11, 147-166.

Smit, D., 2008, 'On belonging: Doing Theology together', in D.C. Marks (ed.), Shaping a global theological mind, pp. 153-162, Ashgate, Hampshire.

Tabensky, P. \& Matthews, S. (eds.), 2015, Being at home: Race, institutional culture and transformation at South African higher education institutions, University of KwaZulu-Natal Press, Pietermaritzburg

Tracy, D., 1981. The analogical imagination: Christian Theology and the culture of pluralism, Crossroads, New York.

Trisk, J., 2015, 'Choosing the better part: Engendering theological education', in M. Naidoo (ed.), Contested issues in training ministers in South Africa, pp. 57-69, SUN MeDIA, Stellenbosch.

UK Benchmark Statement on Theology and Religious Studies, 2007, viewed 1 December 2011, from http://www.qaa.ac.uk/academicinfrastructure/benchmark/ statements/Theology.asp

Vale, P., Hamilton, L. \& Prinsloo, E.H. (eds.), 2014, Intellectual traditions in South Africa: Ideas individuals and institutions, UKZN Press, Pietermaritzburg.

Venter, R. (ed.), 2011, Faith, religion and the public university, Acta Theologica Supplementum 14, SUN MeDIA, Bloemfontein.

Venter, R., 2013, 'Speaking God at a public university in South Africa: The challenge of epistemological transformation', Studia Historiae Ecclesiasticae 39 (Suppl. 1), 231-245.

Venter, R., 2015, 'Transformation, Theology and the public university in South Africa', Acta Theologica 35(2), 173-203.

Venter, R. \& Tolmie, F. (eds.), 2012, Transforming theological knowledge: Essays on Theology and the university after apartheid, SUN MeDIA, Bloemfontein.

Volf, M., 2005, 'Dancing for God: Challenges facing theological education today', Evangelical Review of Theology 29(3), 197-207.

Volf, M., 2015, Flourishing: Why we need religion in a globalised world, Yale, New Haven, CT.

Walls, A.F., 2002, 'Christian scholarship in Africa in the twenty-first century', Transformation 19(4), 217-228.

Welker, M. \& Schweitzer, F. (eds.), 2005, Reconsidering the boundaries between theological disciplines, LIT Verlag, Münster.

Werner, D., 2012, 'Oslo: The future of Theology in the changing landscape of universities in Europe and beyond', The Ecumenical Review 64(3), 393-404. $\mathrm{http}: / / \mathrm{dx}$.doi.org/10.1111/j.1758-6623.2012.00183.x

Werner, D., Esterline, D., Kang, N., \& Raja, J. (eds.), 2010. Handbook of theological education in world Christianity, Regnum, Oxford.

Wethmar, C.J., 1996, 'Wat het Athene met Jerusalem te doen? Enkele historiessistematiese gesigspunte in verband met die vraag of teologie aan die universiteit tuishoort', Skrif en Kerk 17(2), 473-490.

Wingate, A., 2005, 'Overview of the history of the debate about theological education', International Review of Mission 94(373), 235-247. http://dx.doi.org/10.1111/j. 1758-6631.2005.tb00499.x

Zakai, A., 2007, 'The rise of modern science and the decline of Theology as the "queen of sciences" in the early modern era', Reformation and Renaissance Review 9(2), 125-151. http://dx.doi.org/10.1558/rrr.v9i2.125 